\title{
Specify Other Histologic Type
}

National Cancer Institute

\section{Source}

National Cancer Institute. Specify Other Histologic Type. NCI Thesaurus. Code C160676.

A directive to specify the other histologic type. 